\title{
Prevalence of alkane monooxygenase genes in Arctic and Antarctic hydrocarbon-contaminated and pristine soils ${ }^{1}$
}

\author{
L.G. Whyte ${ }^{\mathrm{a}, *}$, A. Schultz ${ }^{\text {a }}$, J.B. van Beilen ${ }^{\mathrm{b}}$, A.P. Luz ${ }^{\mathrm{c}}$, V. Pellizari ${ }^{\mathrm{c}}$, D. Labbé ${ }^{\mathrm{a}}$, \\ C.W. Greer ${ }^{a}$ \\ a Biotechnology Research Institute, National Research Council of Canada, 6100 Royalmount Avenue, Montreal, QC, Canada H4P 2R2 \\ ${ }^{\mathrm{b}}$ Institute of Biotechnology, Swiss Federal Institute of Technology (ETH), ETH-Hönggerberg, CH-8093 Zurich, Switzerland \\ c Biomedical Sciences Institute, University of São Paulo, São Paulo, Brazil
}

Received 21 December 2001; received in revised form 19 April 2002; accepted 23 April 2002

First published online 17 June 2002

\begin{abstract}
The prevalence of four alkane monooxygenase genotypes (Pseudomonas putida GPo1, Pp alkB; Rhodococcus sp. strain Q15, Rh alkB1 and $\mathrm{Rh}$ alkB2; and Acinetobacter sp. strain ADP-1, Ac alkM) in hydrocarbon-contaminated and pristine soils from the Arctic and Antarctica were determined by both culture-independent (PCR hybridization analyses) and culture-dependent (colony hybridization analyses) molecular methods, using oligonucleotide primers and DNA probes specific for each of the alk genotypes. PCR hybridization of total soil community DNA detected the rhodococcal alkB genotypes in most of the contaminated ( $\mathrm{Rh}$ alkB1, 18/20 soils; Rh alkB2, 13/20) and many pristine soils ( $\mathrm{Rh}$ alkB1, 9/10 soils; $\mathrm{Rh}$ alkB2, 7/10), while Pp alkB was generally detected in the contaminated soils (15/20) but less often in pristine soils (5/10). Ac alk $M$ was rarely detected in the soils (1/30). The colony hybridization technique was used to determine the prevalence of each of the alk genes and determine their relative abundance in culturable cold-adapted $\left(5^{\circ} \mathrm{C}\right)$ and mesophilic populations $\left(37^{\circ} \mathrm{C}\right)$ from eight of the polar soils. The cold-adapted populations, in general, possessed relatively higher percentages of the $\mathrm{Rh}$ alkB genotypes ( $\mathrm{Rh}$ alkB1, 1.9\% (0.55); Rh alkB2, 2.47\% (0.89)), followed by the Pp alkB (1.13\% (0.50)), and then the Ac alkM $(0.53 \%(0.36))$. The $\mathrm{Rh}$ alkB1 genotype was clearly more prevalent in culturable cold-adapted bacteria $(1.9 \%(0.55))$ than in culturable mesophiles $(0.41(0.55))$, suggesting that cold-adapted bacteria are the predominant organisms possessing this genotype. Overall, these results indicated that (i) Acinetobacter spp. are not predominant members of polar alkane degradative microbial communities, (ii) Pseudomonas spp. may become enriched in polar soils following contamination events, and (iii) Rhodococcus spp. may be the predominant alkane-degradative bacteria in both pristine and contaminated polar soils. (C) 2002 Federation of European Microbiological Societies. Published by Elsevier Science B.V. All rights reserved.
\end{abstract}

Keywords: Alkane monooxygenase; Alkane degradation; Polymerase chain reaction; Colony hybridization; Arctic; Antarctica

\section{Introduction}

Biodegradation of many of the components of petroleum hydrocarbons by indigenous cold-adapted microbial populations has been observed at low temperatures in

\footnotetext{
* Corresponding author. Tel.: +1 (514) 496 6316;

Fax: +1 (514) 4966265 .

E-mail address: lyle.whyte@nrc.ca (L.G. Whyte).

${ }^{1}$ Issued as NRC 44660 (National Council of Canada).
}

both hydrocarbon-contaminated Antarctic soils [1-3] and Arctic soils [4-9]. Numerous degradative bacteria have recently been isolated from contaminated polar soils and characterized [10-15]. They include both Gram-negative (Pseudomonas, Sphingomonas, Acinetobacter) and Grampositive (Arthrobacter, Rhodococcus) genera and are psychrotrophic rather than psychrophilic. Psychrophilic and psychrotrophic microorganisms are characterized by low temperature growth ranges of $\leq 0^{\circ} \mathrm{C}$ to $15-20^{\circ} \mathrm{C}$ and $\geq 0^{\circ} \mathrm{C}$ to $30-35^{\circ} \mathrm{C}$, respectively, while mesophilic microorganisms possess growth temperature ranges of $\sim 10^{\circ} \mathrm{C}$ to $45-50^{\circ} \mathrm{C}$ [16]. Phylogenetically related rhodococcal and pseudomonad strains have been isolated from the Arctic, Antarctica and from other cold environments [10, $11,13]$. 
Many of the hydrocarbon contaminants found in polar soils contain large $n$-alkane fractions, from $\mathrm{C} 9$ to $\mathrm{C} 15$, for example, in the Antarctica [1], while Arctic diesel fuel, comprised mainly of aliphatics, is a common contaminant in Canadian Arctic soils. Microorganisms capable of degrading alkanes are readily isolated from contaminated and non-contaminated sites but relatively little is known about the genetic characteristics of their alkane degradative systems. Alkane monooxygenases are the key enzymes found in bacterial alkane degradation pathways and, in general, they catalyze the initial terminal oxidation of the alkane substrate to a 1-alkanol, usually as part of a three component alkane hydroxylase complex consisting of a particulate, integral-membrane alkane monooxygenase, and two soluble proteins, rubredoxin and rubredoxin reductase. The alkane monooxygenases from only a small number of Gram-negative bacteria, namely Pseudomonas (Pp alkB; C5-C12 n-alkanes) [17,18] and Acinetobacter (Ac alkM; C10-C20 n-alkanes) $[19,20]$, have been genetically characterized in detail. We have recently found and characterized multiple alkane hydroxylase systems in two Rhodococcus strains (R. erythropolis NRRL B-16531 and Rhodococcus sp. strain Q15) isolated from different geographical locations [21]. Both organisms are alkane degradative psychrotrophs and contain at least four alkane monooxygenase homologues ( $\mathrm{Rh}$ alkB1, $\mathrm{Rh}$ alkB2, $\mathrm{Rh}$ alkB3 and $\mathrm{Rh}$ alkB4). Pseudomonas fluorescens CHAO clones containing rhodococcal alkB2 were able to mineralize and grow on C12-C16 n-alkanes [21]. Rhodococcus sp. strain Q15 has been extensively examined for its ability to assimilate and degrade C12-C32 n-alkanes at low temperatures $[22,23]$. This genus and other closely related actinomycetes are considered important members of hydrocarbon-degrading microbial populations in contaminated soils [24].

$\mathrm{Pp}$ alkB and $\mathrm{Rh}$ alkB homologues are reported to exist in many alkane degradative Gram-negative and Grampositive bacterial strains, respectively [25-28]. However, practically no information is presently available describing the prevalence and geographical distribution of various alkane monooxygenase genes in soils. Fortunately, the alk genes seem to be quite divergent in different genera and especially between the Gram-positive and Gram-negative microorganisms, indicating that it should be possible to construct DNA probes and specific oligonucleotide primers for detecting and monitoring specific alkane monooxygenase genotypes by molecular methods. In the present study, the prevalence of various alkane monooxygenase genotypes in hydrocarbon-contaminated and pristine soils obtained from the Arctic and Antarctic was determined by both culture-independent (PCR hybridization analyses of total soil community DNA) and culture-dependent (colony hybridization analyses of viable heterotrophic populations) molecular methods, using oligonucleotide primers and DNA probes specific for each of the $\mathrm{Pp}$ alkB, Ac alkM, Rh alkB1 and $\mathrm{Rh}$ alkB2 genotypes.

\section{Materials and methods}

\subsection{Soil samples}

Sixteen contaminated and pristine soil samples were obtained from Antarctica, during the summers of 1998 and 1999, at several sites near the Brazilian Antarctic Station Commandante Ferraz (lat. $62^{\circ} 05^{\prime} \mathrm{S}$, long. $58^{\circ} 23.5^{\prime} \mathrm{W}$ ), from areas around the diesel fuel storage tanks, and from other stations and non-contaminated sites distributed along Admiralty and Maxwell bays, on King George Island, South Shetland islands and the Antarctic Peninsula. The samples were collected just below the surface to a depth of approximately $10 \mathrm{~cm}$ with sterile spatulas, sealed in sterile Whirlpak bags, transported on ice to the laboratory, and stored at $-20^{\circ} \mathrm{C}$ until they were analyzed. Fourteen contaminated and pristine soils were collected from various sites (CFS-Alert, $82^{\circ} 30^{\prime} \mathrm{N}, 62^{\circ} 20 \mathrm{~W}$; Eureka High Arctic Weather Station, $75^{\circ} 59^{\prime} \mathrm{N}, 85^{\circ} 48^{\prime} \mathrm{W}$; Mid-Canada Line (MCL), $55^{\circ} 15^{\prime} \mathrm{N}, 75^{\circ} 59^{\prime} \mathrm{W}$; Cape Hope, $61^{\circ} 10^{\prime} \mathrm{N}$, $77^{\circ} 20^{\prime} \mathrm{W}$ ) in the Canadian Arctic and one site in northern Quebec (Mont Apica, 48 ${ }^{\circ} 30^{\prime} \mathrm{N}, 7^{\circ} 25^{\prime} \mathrm{W}$ ) between 1998 and 2000. In all cases, pristine soils with similar soil characteristics to the corresponding contaminated soil(s) were collected from regions $\sim 0.2-1 \mathrm{~km}$ from the corresponding contaminated sites. Soils were collected in sterile containers stored on ice or frozen at $-20^{\circ} \mathrm{C}$ before transport to Montreal for analysis. Upon arrival in Montreal, subsamples of the soils were immediately taken and stored at $-80^{\circ} \mathrm{C}$; these samples were used for the experiments described in this paper which occurred in 2000. Total petroleum hydrocarbons (TPH) were extracted from the Arctic soil samples by sonication in hexane and quantified by GC/MS essentially as described by the Centre d'expertise en analyse environnementale du Québec [29].

\subsection{Design of $P p$ alkB, Ac alkM, Rh alkB1, and Rh alkB2 PCR primers}

For PCR analyses, oligonucleotide primer sets specific for Pp alkB, Ac alkM and Rh Q15 alkB1 and alkB2 were derived by alignment of the predicted amino acid sequences corresponding to the alkane monooxygenase genes by the classic method (GeneWorks, Intelligenetics, Mountain View, CA, USA) and subsequently using the corresponding DNA sequences (Table 1). For specificity of bacterial alkane monooxygenases in general, the reverse primers were chosen from the very highly conserved third histidine box region within the apparent alkane monooxygenase signature motif (LQRH(S/A)DHH) [21]. The three highly conserved histidine boxes of the eight-histidine motif (Hist-1, Hist-2, and Hist-3) are believed to be part of the catalytic sites of these enzymes. The forward primers for $\mathrm{Pp}$ alkB, Ac alkM and Rh Q15 alkB1 were chosen from non-homologous regions to ensure specificity for each of these three genes. The resulting primer sets gave specific 
Table 1

Oligonucleotide sequences of primers and probes and reference strains used in this study

\begin{tabular}{|c|c|c|c|c|}
\hline Strain/alk gene & Sequence $\left(5^{\prime}\right.$ to $\left.3^{\prime}\right)$ & Fragment size $(b p)$ & Reference strains & References \\
\hline \multicolumn{5}{|l|}{ P. putida alkB } \\
\hline $\mathrm{Pp}$ alkB-F & TGGCCGGCTACTCCGATGATCGGAATCTGG & 870 & P. putida ATCC 29347 & [43] $(\mathrm{X} 65936)^{\mathrm{a}}$ \\
\hline Pp alkB-R & CGCGTGGTGATCCGAGTGCCGCTGAAGGTG & & & \\
\hline \multicolumn{5}{|c|}{ Acinetobacter sp. strain ADP-1alkM } \\
\hline Ac alkM-F & $\begin{array}{l}\text { CCTGTCTCATTTGGCGCTCGTTCCTACAGG } \\
\text { GTGATGATCTGAATGTCGTTGTAACTGG }\end{array}$ & 496 & Acinetobacter calcoaceticus ATCC 33315 & [19] (AJ002316) \\
\hline \multicolumn{5}{|c|}{ Rhodococcus sp. strain Q15 alkB1, alkB2 } \\
\hline $\mathrm{Rh}$ alkB1-F & ATCTGGGCGCGTTGGGATTTGAGCG & 629 & Rhodococcus sp. strain Q15 & [21] (AF388181) \\
\hline $\mathrm{Rh}$ alkB1-R & CGCATGGTGATCGCTGTGCCGCTGC & & & \\
\hline $\mathrm{Rh}$ alkB2-F & АCTCTGGCGCAGTCGTTTTACGGCC & 552 & Rhodococcus sp. strain Q15 & [21] (AF388182) \\
\hline $\mathrm{Rh}$ alkB2-R & CCCACTGGGCAGGTTGGGCGCACCG & & & \\
\hline \multicolumn{5}{|c|}{ Universal 16S rDNA primers } \\
\hline $8-\mathrm{F}$ & AGAGTTTGATCCTGGTCCAG & 511 & Eubacteria domain & [34] \\
\hline $519-\mathrm{R}$ & GTATTACCGCGGCTGCTGG & & & \\
\hline
\end{tabular}

${ }^{\mathrm{a}}$ GenBank accession number.

PCR amplification for each of these three genes, using the reference strains listed in Table 1, as positive controls. The $\mathrm{Rh}$ alkB2 primers were chosen from areas of relatively low homology between $\mathrm{Rh}$ alkB1 and $\mathrm{Rh}$ alkB2 (data not shown); nevertheless, some weak cross-amplification did occur between the primers designed for $\mathrm{Rh}$ alkBl and $\mathrm{Rh}$ alkB2.

\subsection{Total community DNA extraction and purification}

To determine the prevalence of the various alkane monooxygenase genotypes in hydrocarbon-contaminated and pristine soils obtained from the Arctic and Antarctica, total community DNA was extracted from the soils and screened by PCR using the alkane monooxygenase primer sets. The total community DNA of $10 \mathrm{~g}$ of each soil sample was extracted using an adapted protocol [30] from Flemming et al. [31], using a lysis treatment and polyvinylpolypyrrolidone (PVPP) purification step [32] to obtain high-quality PCR-amplifiable DNA. Prior to lysis treatment, $4.5 \mathrm{ml}$ of distilled water was added to $10 \mathrm{~g}$ of soil sample. A $500-\mu 1$ aliquot of $250 \mathrm{mM}$ Tris- $\mathrm{HCl}(\mathrm{pH} 8.0)$ and $50 \mathrm{mg}$ lysozyme were added, and the samples were incubated for $30 \mathrm{~min}$ at $30^{\circ} \mathrm{C}$, followed by $30 \mathrm{~min}$ at $37^{\circ} \mathrm{C}$ with mixing by inversion every $10 \mathrm{~min}$. Proteinase $\mathrm{K}$ was added to a final concentration of $20 \mathrm{mg} \mathrm{ml}^{-1}$ and samples were incubated for $1 \mathrm{~h}$ at $37^{\circ} \mathrm{C}$. The lysis treatment was completed with the addition of $500 \mu \mathrm{l}$ of $20 \%$ SDS, and incubated for $30 \mathrm{~min}$ at $85^{\circ} \mathrm{C}$. Samples were centrifuged $(13600 \times g)$ for $10 \mathrm{~min}$ at room temperature. Supernatants were treated with a one-half volume of $7.5 \mathrm{M}$ ammonium acetate, incubated on ice for $15 \mathrm{~min}$ to precipitate proteins and humic acids, and centrifuged for $5 \mathrm{~min}$ at $4^{\circ} \mathrm{C}$ $(13600 \times g)$. The DNA was precipitated with one volume of isopropanol at $-20^{\circ} \mathrm{C}$, overnight. Samples were centrifuged at $4^{\circ} \mathrm{C}$ for $20 \mathrm{~min}(15800 \times \mathrm{g})$. Pellets were washed with $70 \%$ cold ethanol and dried by speed vacuum for approximately $5 \mathrm{~min}$. Each DNA sample was re-suspended in $200 \mu \mathrm{l}$ of Tris-EDTA $(\mathrm{pH} \mathrm{8.0)}$ ) and stored at $-20^{\circ} \mathrm{C}$. To obtain a high-quality PCR-amplifiable DNA, all samples were purified using PVPP spin columns [32].

\subsection{Detection of alkane monooxygenases by PCR and hybridization analyses}

PCR was carried out as described by Whyte et al. [14] for 30 cycles of $1 \mathrm{~min}$ of denaturation at $94^{\circ} \mathrm{C}, 1 \mathrm{~min}$ of annealing at $60^{\circ} \mathrm{C}, 1 \mathrm{~min}$ of extension at $72^{\circ} \mathrm{C}$ and a final extension of $3 \mathrm{~min}$ at $72^{\circ} \mathrm{C}$, using a Perkin Elmer-Cetus DNA thermal cycler 480 (Perkin Elmer-Cetus, Mississauga, ON, Canada). $100 \mathrm{ng}$ of DNA (1-5 $\mu$ l of extract) (quantified using DyNA Quant 200, Hoefer) were used as template for PCR amplification. Amplification products were analyzed on $1.2 \%$ agarose gels followed by ethidium bromide staining to verify if the amplification was successful as described by Sambrook et al. [33]. To confirm that DNA had been successfully extracted from the soils and could be amplified by PCR, universal 16S rDNA eubacterial primers [34] (Table 1) were used as a positive PCR amplification control. PCR amplification of DNA catabolic genes from total community DNA extracted from soils was previously empirically optimized for each set of primers and probes tested. The following reference strains, which were cultured at room temperature on Trypticase Soy Agar (TSA) and stored at $4^{\circ} \mathrm{C}$, were used as positive controls: Pseudomonas putida GPol ATCC 29347 (Pp alk $B^{+}$) (note: formally designated as Pseudomonas oleovorans [18]); Acinetobacter calcoaceticus ATCC 33304 (Ac alkM); Rhodococcus sp. strain Q15 (Rh alkB1 ${ }^{+}, \mathrm{Rh}$ alkB2 ${ }^{+}$). The 496 bp alkM fragment from $A$. calcoaceticus ATCC 33304, obtained by PCR from the primers derived from the Acinetobacter sp. strain ADP-1 sequence, was 
purified, sequenced and found to have $100 \%$ DNA sequence identity with Ac ADP-1 alkM. To verify amplification of the correct PCR fragment, PCR fragments were transferred from the agarose gels to nylon membranes as previously described [14] and analyzed by Southern hybridization with DNA probes specific for $\mathrm{Pp}$ alkB, Ac alkM and Q15 alkB1 and Q15 alkB2, using high stringency prehybridization, hybridization, and washing conditions at $65^{\circ} \mathrm{C}$. The probes were labeled with the DIG nonradioactive nucleic acid labeling and detection system, using the DIG DNA Labeling and Detection kit (Roche Molecular Biochemicals, Laval, QC, Canada). The rhodococcal probes were not completely specific for each of their respective rhodococcal alk $B$ genes, as weak cross-hybridization was observed between the two rhodococcal alk $B$ probes and the $\mathrm{Rh}$ alkB1 and $\mathrm{Rh}$ alkB2 PCR amplification fragments as well as DNA isolated from clones containing $\mathrm{Rh}$ alkB1 or $\mathrm{Rh}$ alkB2 [21]. The PCR detection limits for $\mathrm{Rh}$ alkB1, Pp alkB and Ac alkM were determined by spiking an Arctic soil (Alert P) with a range of concentrations $\left(10^{0}-10^{6} \mathrm{cfu}(\mathrm{g} \text { soil })^{-1}\right)$ of each control strain, extracting the total community DNA and performing PCR analyses for each of alkB genotype, using the soil DNA extraction and PCR amplification protocols used in this study. The detection limits for $\mathrm{Rh}$ alkB1, $\mathrm{Pp}$ alkB and Ac alkM were $\sim 10^{4}$ cells (g soil) ${ }^{-1}$ for visually detecting PCR amplification products. Southern hybridization of the PCR amplification products increased the sensitivity by a further $\sim 10-100$-fold.

\subsection{Colony hybridization analyses}

Total viable aerobic heterotrophic bacteria (i.e. culturable organisms) in eight representative soil samples (four Arctic and four Antarctic) were enumerated by the spread plate method on MSM-YTS medium [35] containing yeast extract, tryptone and starch $\left(250 \mathrm{mg} 1^{-1}\right.$ each) at $5^{\circ} \mathrm{C}$ and $37^{\circ} \mathrm{C}$, to measure the cold-adapted populations (psychrophilic and psychrotrophic bacteria) and mesophilic populations, respectively. The percentage of colonies possessing alkane monooxygenase genotypes was determined by colony hybridization [35]. The colonies from the viable count plates were transferred onto nylon membranes and examined by hybridization analysis for hydrocarbon-degrading bacteria using Pp alkB, Ac alkM and Q15 alkB1 and Q15 alkB2 gene probes (prepared as described above), using high-stringency prehybridization, hybridization and washing at $65^{\circ} \mathrm{C}$, followed by luminography. Two sets of spread plates were prepared for each incubation temperature: one set of spread plates was lifted and probed first with $\mathrm{Pp}$ alkB, stripped, and then probed with $\mathrm{Rh}$ alkB1; the second set was lifted, probed first with Ac alkM, stripped, and then probed with $\mathrm{Rh}$ alkB2. Non-radioactive DNA probe labeling and DNA hybridization and stripping were done according to the DIG Application Manual for Filter Hybridization (Roche Molecular Biochemicals).
In total, $\sim 10000$ colonies were screened for each alkB genotype.

\section{Results and discussion}

The prevalence of the various alkane monooxygenase genotypes ( $\mathrm{Pp}$ alkB, Ac alkM, Q15 alkB1 and Q15 alkB2) was determined in hydrocarbon-contaminated and pristine soils obtained from the Arctic and Antarctic by culture-independent (PCR hybridization) and culture-dependent (colony hybridization) molecular methods. Both molecular approaches used in this study were successful in specifically detecting distinct alkane monooxygenase genes in the polar soils.

\subsection{PCR-based methods to detect alk-genes in soils}

PCR amplification of the correct 16S rDNA fragment was obtained from all soil extracts (data not shown), indicating that soil DNA had been successfully extracted and inhibition of the PCR reaction had not occurred. PCR analyses of DNA extracts from polar soils resulted in the amplification of DNA fragments of a size comparable to that of the positive controls for the four alkane monooxygenase genes. In most cases, these fragments hybridized, using high stringency conditions, to the corresponding gene probe, indicating that the amplified PCR fragments possessed a high level of sequence identity to the corresponding target catabolic genes studied, as shown for a representative gel (Fig. 1). Properly sized PCR fragments sometimes did not hybridize to their respective gene probes, indicating that distantly related alkane monooxygenase genotypes or spurious PCR fragments had been amplified. PCR fragments that were not visually detected by ethidium bromide staining were sometimes detected by subsequent hybridization analysis because of the greater sensitivity of the hybridization technique, thus reducing the possibility of false negatives. The number of target copies in the DNA extract may have been relatively low or some inhibition of the PCR reaction may have occurred, resulting in the amplification of relatively small amounts of the target gene, only detectable by hybridization.

The rhodococcal alkB1 and alkB2 genotypes were detected by PCR hybridization in most of the contaminated soils (Table 2) and non-contaminated soils (Table 3) from both the Arctic and the Antarctic. For example, Rh alkB1 could be detected in $90 \%$ of the contaminated polar soils and $90 \%$ of the pristine soils (percentage of soils that gave a positive or weak hybridization signal from the PCR amplification products). The rhodococcal alkB2 genotype was also detected in many of the contaminated $(65 \%)$ and pristine soils $(60 \%)$, although to a lesser extent than $\mathrm{Rh}$ alkB1. The presence of the $\mathrm{Rh}$ alkB1 and $\mathrm{Rh}$ alkB2 genotypes detected in many of the pristine polar soils indicates that these types of organisms are present in substantial 


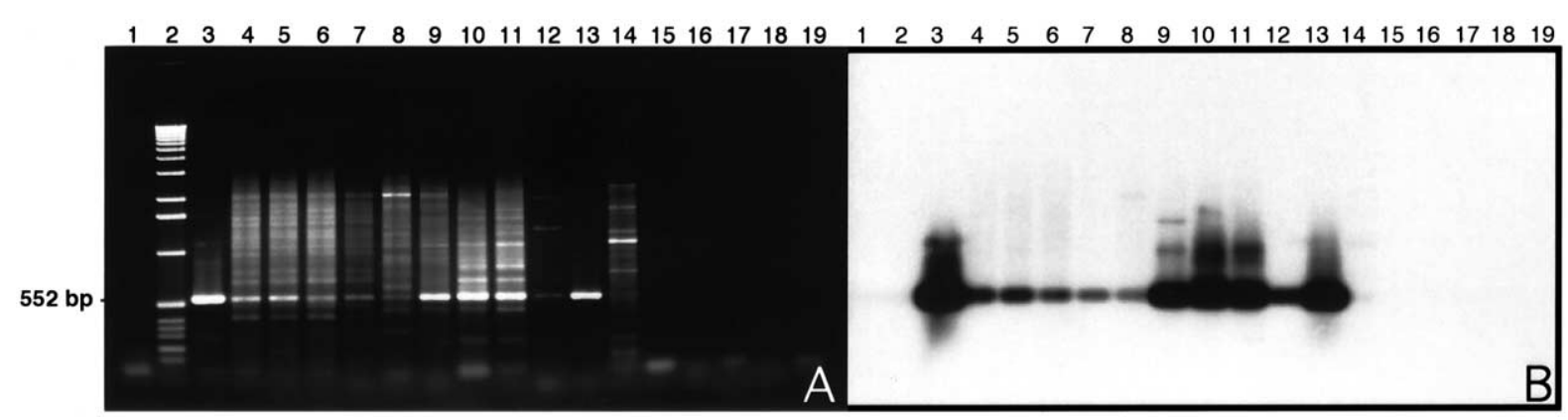

Fig. 1. Detection of Rh alkB2 by PCR analysis and Southern hybridization in Antarctic soils. A: Agarose gel electrophoresis (1.2\%) showing the expected 552-bp alkB2 fragment obtained by PCR analysis of DNA extracts from Antarctic soils. B: Southern hybridization analysis of alkB2 PCR fragments shown in A transferred to a nylon membrane and probed with the 552-bp alkB2 gene probe derived from Rhodococcus sp. strain Q15. Lanes: 1, $\mathrm{H}_{2} \mathrm{O}$ (negative control); 2, 1-kb ladder; 3, Rhodococcus sp. strain Q15 (alkB2+); 4, Ant-1A; 5, Ant-1B; 6, Ant-2A; 7, Ant-2B; 8, Ant-3A; 9, Ant-3B; 10, Ant-4A; 11, Ant-4B; 12, Ant-5; 13, Ant-Fer17; 14, Ant-Fer18; 15, Ant-FLD02; 16, Ant-FLD04; 17, Ant-FLD10; 18, Ant-FLD12; 19, AntFLD06.

numbers before hydrocarbon-contamination events occur. In comparison, $\mathrm{Pp}$ alkB was detected in many of the contaminated polar soils $(75 \%)$ but was not detected to the same extent in pristine polar soils $(50 \%)$. This was especially true in Antarctic pristine soils where PCR Pp alkB fragments could not be visually detected, although weak hybridization signals were observed from two of the five soils analyzed. These results suggest that organisms containing these genotypes are enriched following hydrocarbon contamination. Ac alkM was not detected by PCR and hybridization analyses in any of the Antarctic soils and in only one Arctic soil. In a similar study using the same methodology, neither $\mathrm{Pp}$ alkB nor Ac alkM was detected in Brazilian pristine and contaminated soil samples while the $\mathrm{Rh}$ alkB1 and $\mathrm{Rh}$ alkB2 genes were found in the most of the soils (A.P. Luz and V.H. Pellizari, personal communication). In general, there were no clear differences observed in alk gene prevalence between the Arctic and the Antarctic.

\subsection{Colony hybridization to detect alk genes in soils}

The colony hybridization technique was used to detect the presence of the alk genes and characterize their relative abundance in culturable cold-adapted $\left(5^{\circ} \mathrm{C}\right)$ and mesophilic populations $\left(37^{\circ} \mathrm{C}\right)$ from eight of the polar soils. Viable

Table 2

Screening ${ }^{\mathrm{a}}$ for various alkane monooxygenase genes in contaminated Arctic and Antarctic soils

\begin{tabular}{|c|c|c|c|c|c|c|c|c|c|}
\hline \multirow[t]{2}{*}{ Contaminated soils } & \multirow[t]{2}{*}{ TPH $\left(\mathrm{mg} \mathrm{kg}^{-1}\right)$} & \multicolumn{2}{|c|}{ Pp alkB } & \multicolumn{2}{|c|}{$\mathrm{Rh}$ alkBl } & \multicolumn{2}{|c|}{$\mathrm{Rh}$ alkB2 } & \multicolumn{2}{|c|}{ Ac alkM } \\
\hline & & PCR & Probe & PCR & Probe & PCR & Probe & PCR & Probe \\
\hline \multicolumn{10}{|l|}{ Antarctic } \\
\hline Ant-1A & & + & + & + & + & + & + & - & - \\
\hline Ant-1B & & + & - & + & + & + & + & - & - \\
\hline Ant-2A & & + & + & + & + & + & + & - & - \\
\hline Ant-2B & & + & $\mathrm{w}$ & + & + & + & + & - & - \\
\hline Ant-4A & & + & + & + & + & + & + & - & - \\
\hline Ant-4B & & + & + & + & + & + & + & - & - \\
\hline Ant-5 & & + & + & + & + & + & + & - & - \\
\hline Ant-FLD2 & & - & - & + & + & - & - & - & - \\
\hline Ant-FLD4 & & - & + & - & - & + & - & - & - \\
\hline Ant-FLD10 & & - & - & + & + & + & - & - & - \\
\hline Ant-FLD12 & & - & - & + & + & + & - & - & - \\
\hline \multicolumn{10}{|l|}{ Arctic } \\
\hline Alert \#1 & 26900 & + & + & + & + & + & + & - & - \\
\hline Alert \#4 & 8100 & + & + & + & + & + & + & + & + \\
\hline Eureka \#1 & 5166 & + & + & + & + & - & - & - & - \\
\hline Eureka \#3 & 4500 & + & + & + & + & + & + & - & - \\
\hline Kuujjuaq \#2 & 1400 & + & + & + & + & + & + & - & - \\
\hline Kuujjuaq \#4 & 2100 & - & $\mathrm{w}$ & + & + & - & $\mathrm{w}$ & - & - \\
\hline Mont Apica & 56100 & + & + & - & - & + & + & - & - \\
\hline $\mathrm{MCL}$ & 30500 & - & - & + & + & - & - & - & - \\
\hline Cape Hope \#5 & 17400 & + & + & + & + & - & - & - & - \\
\hline
\end{tabular}

${ }^{a}+$ indicates positive hybridization; - indicates no hybridization; w indicates weak hybridization. 
Table 3

Screening ${ }^{\mathrm{a}}$ for various alkane monooxygenase genes in pristine Arctic and Antarctic soils

\begin{tabular}{|c|c|c|c|c|c|c|c|c|c|}
\hline \multirow[t]{2}{*}{ Pristine soils } & \multirow[t]{2}{*}{$\mathrm{TPH}\left(\mathrm{mg} \mathrm{kg}^{-1}\right)$} & \multicolumn{2}{|c|}{ Pp alkB } & \multicolumn{2}{|c|}{$\mathrm{Rh}$ alkB1 } & \multicolumn{2}{|c|}{$\mathrm{Rh}$ alkB2 } & \multicolumn{2}{|c|}{ Ac alkM } \\
\hline & & PCR & Probe & PCR & Probe & PCR & Probe & PCR & Probe \\
\hline \multicolumn{10}{|l|}{ Antarctica } \\
\hline Ant-3A & & - & $\mathrm{w}$ & + & + & + & + & - & - \\
\hline Ant-3B & & - & - & + & + & + & + & - & - \\
\hline Ant-FLD6 & & - & - & + & + & - & - & - & - \\
\hline Ant-FER17 & & - & - & + & + & + & + & - & - \\
\hline Ant-FER 18 & & - & + & + & + & + & $\mathrm{w}$ & - & - \\
\hline \multicolumn{10}{|l|}{ Arctic } \\
\hline Alert - p & $<100$ & - & $\mathrm{w}$ & - & $\mathrm{w}$ & + & + & - & - \\
\hline Eureka - p & & + & + & + & + & - & - & - & - \\
\hline Kuujjuaq \#3 & 200 & - & - & + & - & + & + & - & - \\
\hline $\mathrm{MCL}-\mathrm{p}$ & $<100$ & + & + & + & + & - & - & - & - \\
\hline Cape Hope - p & $<100$ & - & - & - & + & - & + & - & - \\
\hline
\end{tabular}

${ }^{a}$ See Table 2 for explanation of symbols.

plate counts at $5^{\circ} \mathrm{C}$ and $37^{\circ} \mathrm{C}$ showed that the coldadapted heterotrophic populations were more numerous (1.6- to $\sim 10^{5}$-fold) than the corresponding mesophilic populations in the polar soils (Table 4). Colony hybridization with the alkane monooxygenase gene probes indicated that culturable bacteria from all of the polar soils contained $\mathrm{Pp}$ alkB, $\mathrm{Rh}$ alkB1, $\mathrm{Rh}$ alkB2 and Ac alkM (except Alert - p) genotypes (Table 4). Direct comparison of the prevalence of these genotypes within a soil indicated that most of the cold-adapted populations (6/8 soils) con- tained at least two-fold more of the $\mathrm{Rh}$ alkBl and/or $\mathrm{Rh}$ alkB2 genotypes than $\mathrm{Pp}$ alkB. None of the $5^{\circ} \mathrm{C}$ populations contained higher percentages of $\mathrm{Pp}$ alkB than $\mathrm{Rh}$ alkB1 or $\mathrm{Rh}$ alkB2 (Table 4). The percentages of $\mathrm{Pp}$ alk $B$ were sometimes higher in the mesophilic populations than $\mathrm{Rh}$ alkB1 (four soils) and $\mathrm{Rh}$ alkB2 (three soils). The Ac alk $M$ genotype was found in many of the viable populations from the polar soils, especially those originating from the Antarctic, but was less prevalent than Rh alkB1 and $\mathrm{Rh}$ alkB2 and, to a lesser extent, $\mathrm{Pp}$ alkB.

Table 4

Microbial enumeration and colony hybridization analyses for various alkane monooxygenase genes in Arctic and Antarctic soils

\begin{tabular}{|c|c|c|c|c|c|c|}
\hline \multirow[t]{2}{*}{ Soils } & \multirow{2}{*}{$\begin{array}{l}\text { Incubation temperature } \\
\left({ }^{\circ} \mathrm{C}\right)\end{array}$} & \multirow{2}{*}{$\begin{array}{l}\text { Viable counts } \\
\left(\mathrm{cfu}(\mathrm{g} \text { soil })^{-1}\right)\end{array}$} & \multicolumn{4}{|c|}{ Colony hybridization (\%) } \\
\hline & & & Pp alkB & $\mathrm{Rh}$ alkB1 & $\mathrm{Rh}$ alkB2 & Ac alkM \\
\hline \multicolumn{7}{|l|}{ Antarctic } \\
\hline \multirow[t]{2}{*}{ Ant-1B - c } & 5 & $4.6 \times 10^{7 \mathrm{a}}$ & $1.7^{\mathrm{b}}(0.35)$ & $2.7(0.6)$ & $2.7(1.2)$ & $\mathbf{0 . 2 6}(0.1)$ \\
\hline & 37 & $6.2 \times 10^{5}$ & $1.4(0.59)$ & $0.5(0.17)$ & $1.2(0.3)$ & 0 \\
\hline \multirow[t]{2}{*}{ Ant $-2 A-c$} & 5 & $1.4 \times 10^{7}$ & $1.2(0.3)$ & $2.0(0.17)$ & $2.4(0.25)$ & $0.9(0.13)$ \\
\hline & 37 & $9.0 \times 10^{6}$ & $1.3(0.26)$ & $0.7(0.18)$ & $0.4(0.1)$ & 0 \\
\hline \multirow[t]{2}{*}{ Ant-FDL10 - c } & 5 & $2.9 \times 10^{6}$ & $1.8(1.3)$ & $2.4(0.19)$ & $4.3(0.36)$ & $1.2(0.29)$ \\
\hline & 37 & $<100$ & 0 & 0 & 0 & 0 \\
\hline \multirow[t]{2}{*}{ Ant-3B - p } & 5 & $1.3 \times 10^{7}$ & $1.1(0.30)$ & $1.9(0.70)$ & $2.7(0.51)$ & $\mathbf{0 . 3}(0.24)$ \\
\hline & 37 & $6.5 \times 10^{3}$ & $3.6(0.5)$ & $1.7(0.80)$ & $0.96(0.29)$ & 0 \\
\hline \multicolumn{7}{|l|}{ Arctic } \\
\hline \multirow[t]{2}{*}{ Alert \#1 - c } & 5 & $8.5 \times 10^{7}$ & $0.2(0.12)$ & $1.1(0.14)$ & $1.9(0.17)$ & $\mathbf{0 . 5 8}(0.05)$ \\
\hline & 37 & $8.3 \times 10^{6}$ & $0.4(0.14)$ & $0.4(0.17)$ & $3.4(1.2)$ & $1.2(0.7)$ \\
\hline \multirow[t]{2}{*}{ Eureka \#3-c } & 5 & $1.6 \times 10^{7}$ & $1.5(0.38)$ & $1.0(0.26)$ & $0.87(0.10)$ & $\mathbf{0 . 3 7}(0.25)$ \\
\hline & 37 & $1.5 \times 10^{5}$ & $1.2(0.40)$ & 0 & $2.3(0.09)$ & $0.26(0.20)$ \\
\hline \multirow[t]{2}{*}{ Alert - p } & 5 & $1.1 \times 10^{6}$ & $0.64(0.20)$ & $2.1(0.51)$ & $2.6(0.30)$ & 0 \\
\hline & 37 & $1.2 \times 10^{2}$ & 0 & 0 & 0 & 0 \\
\hline \multirow[t]{2}{*}{ Eureka - p } & 5 & $7.0 \times 10^{7}$ & $0.96(0.49)$ & $2.0(0.16)$ & $2.4(0.47)$ & $\mathbf{0 . 6 2}(0.19)$ \\
\hline & 37 & $5.3 \times 10^{6}$ & $1.3(0.52)$ & 0 & $0.65(0.20)$ & $1.7(0.49)$ \\
\hline
\end{tabular}

${ }^{a}$ Values represent the mean cfu ( $\mathrm{g}$ soil) ${ }^{-1}$ from triplicate YTS plates; the mean variability of the 16 viable plate counts was $16.5 \%$ (12\%) of the average triplicate plate count.

${ }^{b}$ Values represent the mean percentage (S.D. is shown in parentheses) of probe positive cfu from triplicate YTS plates. Values shown in bold represent soil samples where PCR hybridization failed to detect the corresponding gene (see Tables 2 and 3); c, contaminated; p, pristine. 
Table 5

Global summary of the mean relative percentages of the alk genotypes (\% probe positive) for the eight polar soils examined by colony hybridization

\begin{tabular}{|c|c|c|c|c|}
\hline Incubation temperature and soils & $\mathrm{Pp}$ alkB & $\mathrm{Rh}$ alkB1 & $\mathrm{Rh}$ alkB2 & Ac alkM \\
\hline \multicolumn{5}{|l|}{$5^{\circ} \mathrm{C}$ populations } \\
\hline Contaminated & $1.28^{\mathrm{a}}(0.58)$ & $1.84(0.68)$ & $2.4(1.1)$ & $0.66(0.35)$ \\
\hline Pristine & $0.90(0.19)$ & $2.00(0.08)$ & $2.6(0.12)$ & $0.30(0.25)$ \\
\hline Contaminated + Pristine & $1.13(0.5)$ & $1.90(0.55)$ & $2.47(0.89)$ & $0.53(0.36)$ \\
\hline \multicolumn{5}{|l|}{$37^{\circ} \mathrm{C}$ populations } \\
\hline Contaminated & $0.86(0.56)$ & $0.32(0.28)$ & $1.5(1.3)$ & $0.29(0.46)$ \\
\hline Pristine & $1.6(1.5)$ & $0.56(0.80)$ & $0.54(0.40)$ & $0.57(0.80)$ \\
\hline Contaminated + Pristine & $1.15(1.08)$ & $0.41(0.55)$ & $1.11(1.11)$ & $0.40(0.62)$ \\
\hline \multicolumn{5}{|l|}{ Both $5^{\circ} \mathrm{C}$ and $37^{\circ} \mathrm{C}$ populations } \\
\hline All soils & $1.14(0.84)$ & $1.17(0.92)$ & $1.80(1.20)$ & $0.46(0.51)$ \\
\hline All Antarctic soils & $1.51(0.94)$ & $1.49(0.91)$ & $1.82(1.34)$ & $0.33(0.44)$ \\
\hline All Arctic soils & $0.78(0.51)$ & $0.83(0.81)$ & $1.77(1.07)$ & $0.59(0.55)$ \\
\hline All contaminated soils & $1.7(0.64)$ & $1.1(0.92)$ & $1.9(1.3)$ & $0.48(0.45)$ \\
\hline All pristine soils & $1.3(1.0)$ & $1.3(0.93)$ & $1.6(1.1)$ & $0.44(0.61)$ \\
\hline
\end{tabular}

${ }^{a}$ Values represent the mean percentage (S.D. is shown in parentheses) of probe positive cfu from the eight corresponding pristine and contaminated polar soils.

\subsection{Comparison of cold-adapted and mesophilic populations}

Direct comparison of cold-adapted populations with mesophilic populations for a specific genotype within a soil revealed some interesting differences (Table 4). Higher percentages of $\mathrm{Rh}$ alkB1 (in seven soils) and, to a lesser extent, $\mathrm{Rh}$ alkB2 (in six soils) were found in cold-adapted populations than in mesophilic populations. In contrast, the percentages of $\mathrm{Pp}$ alkB in $5^{\circ} \mathrm{C}$ and $37^{\circ} \mathrm{C}$ populations were roughly equal in the four soils examined, greater in $5^{\circ} \mathrm{C}$ populations from two soils, and greater in $37^{\circ} \mathrm{C}$ populations from two soils. Ac alkM was only detected in the cold-adapted populations in the Antarctic soils, while two of four Arctic soils had higher percentages of Ac alkM within the $37^{\circ} \mathrm{C}$ populations than within the $5^{\circ} \mathrm{C}$ populations. However, in absolute terms, the numbers of coldadapted bacteria possessing the four alk genotypes were always higher (at least two-fold) than the numbers of the corresponding mesophilic bacteria from the same soil, with one exception (Ant-2A, Pp alkB) (data not shown). In two soils (Alert - p, FDL-10), cold-adapted bacteria were much more abundant than mesophilic bacteria (four orders of magnitude) and the four alk genotypes were only detected in the $5^{\circ} \mathrm{C}$ populations. Overall, these results suggest that the cold ambient temperatures have selected for cold-adapted alkane degradative microbial populations in these soils.

A global comparison of the mean relative percentages of the alk genotypes from all of the polar soils examined by colony hybridization is shown in Table 5. As would be expected in comparisons of different soils, the variability of the data determined by the S.D. of the means, was quite high, indicating that the differences between averages were not statistically significant in most comparisons. Nevertheless, the trend discussed above was also present; the $\mathrm{Rh}$ alkB genotypes were generally the most abundant in coldadapted populations, followed by $\mathrm{Pp}$ alkB and then Ac
alkM. In another culture-independent analysis (DGGE) of Arctic soils, high $\mathrm{G}+\mathrm{C}$ Gram-positive organisms were found to predominate, representing $63.6 \%$ of the DGGE bands sequenced compared to $36.4 \%$ identified as Proteobacteria [36]. Relatively high numbers of rhodococci, which have a superior ability to survive freezing temperatures, may be an inherent feature of microbial communities in polar soils and other cold environments characterized by frequent freezing and thawing. For example, an Arctic Rhodococcus strain was recently shown to predominate in an Arctic soil community following a freeze-thaw regime [37]. Gram-positive microorganisms, in general, were better able to survive below freezing temperatures in hydrocarbon-contaminated Antarctic soils [38]. In this study, freezing and thawing during sample collection and processing may also have adversely effected the viability of Gram-negative bacteria, resulting in lower viable plate counts than actually existed at the time of sampling. Pp alkB genes may also be widespread amongst soil pseudomonads because they can be located on a plasmid ( $P$. putida GPol OCT-plasmid) or contained within a class one transposon ( $P$. putida P1 TnPpu-alk1) [18]. Interestingly, the $\mathrm{Rh}$ alkBl genotype was clearly more prevalent in cold-adapted culturable bacteria than in mesophiles (Table 5), suggesting that predominantly cold-adapted bacteria possess this genotype.

\subsection{Comparison of PCR hybridization and colony hybridization for detecting alk genes}

Direct comparison of the results obtained using the two techniques is difficult to interpret as the PCR-based method detects specific genotypes in total DNA extracts, representing theoretically $100 \%$ of the microbial population, whilst the colony hybridization method detects specific genotypes only in culturable bacteria which represent perhaps $\sim 1 \%$ of the soil microbial community [39]. On the 
other hand, the primers and probes used for the cultureindependent method were derived from three genera of readily culturable organisms commonly isolated from hydrocarbon-contaminated soils, allowing for some valid comparisons. One advantage of the culture-based method is that it allows for some additional characterization of the composition of specific genotypes within a population, for example, differences in the relative abundance of specific genotypes at different growth temperatures, as shown in this study. Colony-hybridization results generally agreed with the PCR hybridization results in that both techniques indicated the general trend that rhodococcal alk $B$ genotypes were more abundant than $\mathrm{Pp}$ alkB genotypes and, that relatively low numbers of alkM genotypes were present in the polar soils. The colony-hybridization technique was more sensitive than PCR hybridization, for example, in that it clearly detected alkM genotypes in all soils, and $\mathrm{Pp}$ alkB genotypes in three soils, where PCR hybridization did not (Table 4). The PCR hybridization false negatives observed do not appear to be the result of low target gene copy numbers as colony hybridization data showed that numbers of $a l k^{+}$bacteria ranged from $10^{4}$ to $10^{6} \mathrm{cfu}$ (g soil wet weight) ${ }^{-1}$, similar to numbers observed where PCR hybridization was successful, and within the range of $\sim 10^{4}-10^{6}$ gene copies ( $\mathrm{g}$ soil dry weight $)^{-1}$ thought to be required for successful PCR detection [40] and within the PCR detection limit $\left(\sim 10^{4}\right.$ cells $(\mathrm{g} \text { soil })^{-1}$ ) of the protocols used in this study.

The failure to detect Ac alkM by the PCR method could be attributable to the design of the alkM primers. They may have been too specific to amplify Acinetobacter alkM homologues. Comparison of the primer sequences, derived from ADP-1, with other Acinetobacter alkM sequences recently reported (EB104 [27]; M1 alkMa and alkMb [41]) revealed that the reverse primer $(79 \%-85 \%)$ and especially the forward primer $(62 \%-75 \%)$ had relatively low DNA sequence identities to the corresponding target sequences in these alkM genes, probably resulting in low amplification efficiency of the other putative alkM genes and, consequently, their lack of detection by PCR hybridization. To check this possibility, five Acinetobacter strains (ADP-1, EB104, 69-V, NRRLB-2769A, NCIB 8250; [25]) were analyzed by PCR with the Ac alkM primer set; only the type strain (Ac ADP-1) was alkM PCR positive. In contrast, colony hybridization does not rely on PCR amplification and may be less specific, and thus more sensitive, as the 497-nt Ac alkM gene probe probably had sufficient homology with the corresponding regions of EB104 alkM (80\%) and alkMa (79\%) to hybridize to these and other related alkM homologues. In a separate study, a similar Acinetobacter sp. strain ADP-1 alkM probe did hybridize with $A$. calcoaceticus EB104 alkM and A. calcoaceticus $69-\mathrm{V}$ alkM $(68 \%)$ by colony hybridization and colony blotting [27]. The PCR-based method indicated that $\mathrm{Rh}$ alkB1 was more prevalent than $\mathrm{Rh}$ alkB2 while colony hybridization results indicated the reverse. This may also be attributable to the $\mathrm{Rh}$ alkB2 primers being too specific. The Rh alkB2 PCR reverse primer used did not originate from the highly conserved Hist- 3 motif, unlike the $\mathrm{Rh}$ alkB1-R primer; thus, relatively specific PCR amplification of $\mathrm{Rh}$ alkB2, compared with $\mathrm{Rh}$ alkB1, may have occurred. In comparison, the PCR primers used for $\mathrm{Pp}$ alkB in this study were shown to be the most effective of four different primer sets (derived from $\mathrm{Pp}$ alk $B$ ) in amplifying similar alkB homologues from a variety of pseudomonads growing solely on short-chain alkanes (C10) [26]. Unlike PCR hybridization, colony hybridization did not show that Pp alkB had been enriched for in the contaminated soils. In our experience, organisms containing $\mathrm{Pp}$ alkB and other hydrocarbon-degradative genotypes (ndoB, naphthalene; $x y l E, \mathrm{BTEX)}$ are usually less common in pristine soils, suggesting that hydrocarbondegradative organisms had been selectively enriched for in contaminated soils, a characteristic commonly observed at sites previously contaminated with hydrocarbons [42]. The above discrepancies may also be explained by differential growth of target bacteria under the culture conditions used, perhaps resulting in the selective enrichment and/or inhibition of specific bacterial populations.

\subsection{Concluding remarks}

The two molecular methods used in this study successfully detected the four alkane monooxygenase genes and demonstrated the presence of significant indigenous populations of culturable cold-adapted hydrocarbon-degrading bacteria in the contaminated and pristine polar soils. Both the numbers of cold-adapted microorganisms and cold-adapted alkane degradative organisms ( $\mathrm{Pp}$ alk $B^{+}$,

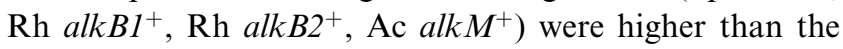
mesophilic populations in the polar soils, emphasizing the important role that cold-adapted microbial communities would play in bioremediation of contaminated soil in polar habitats. The results from both methods indicated that Rhodococcus spp. may be the most abundant alkane degradative bacteria, of the tested genotypes, in contaminated and pristine Arctic and Antarctic soils. Pseudomonas spp. may become enriched in polar soils following contamination events, and Acinetobacter spp. are not predominant members of the polar alkane degradative microbial communities. Other bacterial populations, containing novel divergent homologous alk $B$ genes that were not detected in this study, may also exist in these soils. Although alkane degradative activity in all of these soils was not measured, other studies have clearly indicated that alkane mineralization activity readily occurs in two of the Arctic soils (Alert \#1 and Alert \#4 [8]; Eureka \#1 and \#3 [9]) and Antarctic soils [1] when nutrients were provided. The molecular methods used here can determine the prevalence and composition of specific alkane degradative populations in contaminated soils and thus aid both in assessing the biotreatability of contaminated soils and in monitoring 
the effects on specific populations during bioremediation operations. In addition, the ability to determine the alkane degradative composition of a microbial soil community should also help develop appropriate bioremediation strategies for a particular site. For example, the presence of large numbers of alkane degradative rhodococci, known to produce cell-surface associated biosurfactant(s) with activity at cold temperatures and to directly adhere to solid alkanes at low temperatures [23], would eliminate the need to incorporate a surfactant treatment as part of bioremediation strategy for a contaminated polar soil.

\section{Acknowledgements}

The authors gratefully acknowledge the technical contributions of Nathalie Fortin and Julie Dagenais, and Public Works and Government Services Canada and the Department of National Defence of Canada for access to their sites in Northern Canada.

\section{References}

[1] Aislabie, J., Mcleod, M. and Fraser, R. (1998) Potential for biodegradation of hydrocarbons in soil from the Ross Dependency, Antarctica. Appl. Microbiol. Biotechnol. 49, 210-214.

[2] MacCormack, W.P. and Fraile, E.R. (1997) Characterization of a hydrocarbon degrading psychrotrophic Antarctic bacterium. Antarct. Sci. 9, 150-155.

[3] Margesin, R. and Schinner, F. (2001) Biodegradation and bioremediation of hydrocarbons in extreme environments. Appl. Microbiol. Biotechnol. 56, 650-663.

[4] Braddock, J.F., Ruth, M.L., Catterall, P.H., Walworth, J.L. and McCarthy, K.A. (1997) Enhancement and inhibition of microbial activity in hydrocarbon-contaminated arctic soils: implications for nutrient-amended bioremediation. Environ. Sci. Technol. 31, 20782084.

[5] Mohn, W.W. and Stewart, W.W. (2000) Limiting factors for hydrocarbon biodegradation at low temperature in Arctic soils. Soil Biol. Biochem. 32, 1161-1172.

[6] Mohn, W.W., Radziminski, C.Z., Fortin, M.C. and Reimer, K.J. (2001) On site bioremediation of hydrocarbon-contaminated Arctic tundra soils in inoculated biopiles. Appl. Microbiol. Biotechnol. 57, 242-247.

[7] Westlake, D.W.S., Jobson, A., Phillippe, R. and Cook, F.D. (1974) Biodegradability and crude oil composition. Can. J. Microbiol. 20, 915-928.

[8] Whyte, L.G., Bourbonnière, L., Bellerose, C. and Greer, C.W. (1999) Bioremediation assessment of hydrocarbon-contaminated soils from the high Arctic. Bioremediation J. 3 (1), 69-79.

[9] Whyte, L.G., Goalen, B., Hawari, J., Labbé, D., Greer, C.W. and Nahir, M. (2001) Bioremediation treatability assessment of hydrocarbon contaminated soils from Eureka, Nunavut. Cold Reg. Sci. Technol. 32, 121-132.

[10] Aislabie, J., Foght, J. and Saul, D. (2000) Aromatic hydrocarbondegrading bacteria from soil near Scott Base, Antarctica. Polar Biol. 23, 183-188.

[11] Aislabie, J., Fraser, R., Duncan, S. and Farrell, R.L. (2001) Effects of oil spills on microbial heterotrophs in Antarctic soils. Polar Biol. 24, 308-313.

[12] Bej, A.K., Saul, D. and Aislabie, J. (2000) Cold-tolerant alkane-de- grading Rhodococcus species from Antarctica. Polar Biol. 23, 100105.

[13] Panicker, G., Aislabie, J., Saul, D. and Bej, A.K. (2001) Cold tolerance of Pseudomonas sp. 30-3 isolated from oil-contaminated soil, Antarctica. Polar Biol. 25, 5-11.

[14] Whyte, L.G., Greer, C.W. and Inniss, W.I. (1996) Assessment of the biodegradation potential of psychrotrophic microorganisms. Can. J. Microbiol. 42, 99-106.

[15] Whyte, L.G., Bourbonnière, L. and Greer, C.W. (1997) Biodegradation of petroleum hydrocarbons by psychrotrophic Pseudomonas strains possessing both alkane (alk) and naphthalene (nah) catabolic pathways. Appl. Environ. Microbiol. 63, 3719-3723.

[16] Morita, R.Y. (1975) Psychrophilic bacteria. Bacteriol. Rev. 39, 144 167.

[17] van Beilen, J.B., Wubbolts, M.G. and Witholt, B. (1994) Genetics of alkane oxidation by Pseudomonas oleovorans. Biodegradation 5, 161174.

[18] van Beilen, J.B., Panke, S., Lucchini, S., Franchini, A.G., Röthlisberger, M. and Witholt, B. (2001) Analysis of Pseudomonas putida alkane degradation gene clusters and flanking insertion sequences: evolution and regulation of the alk-genes. Microbiology 147, 16211630.

[19] Ratajczak, A., Geißdörfer, W. and Hillen, W. (1998) Alkane hydroxylase from Acinetobacter sp. strain ADP-1 is encoded by alkM and belongs to a new family of bacterial integral-membrane hydrocarbon hydroxylases. Appl. Environ. Microbiol. 64, 1175-1179.

[20] Ratajczak, A., Geißdörfer, W. and Hillen, W. (1998) Expression of alkane hydroxylase from Acinetobacter sp. strain ADP1 is induced by a broad range of $n$-alkanes and requires the transcriptional activator AlkR. J. Bacteriol. 180, 5822-5827.

[21] Whyte, L.G., Smits, T., Labbé, D., Witholt, B., Greer, C.W., and van Beilen, J.B. (2001) Cloning and characterization of multiple alkane hydroxylases in Rhodococcus sp. strains 16531 and Q15. Appl. Environ. Microbiol. (submitted).

[22] Whyte, L.G., Hawari, J., Zhou, E., Bourbonnière, L., Inniss, W.E. and Greer, C.W. (1998) Biodegradation of variable-chain-length alkanes at low temperatures by a psychrotrophic Rhodococcus sp. Appl. Environ. Microbiol. 64, 2578-2584.

[23] Whyte, L.G., Slagman, S.J., Pietrantonio, F., Bourbonnière, L., Koval, S.F., Lawrence, J.R., Inniss, W.E. and Greer, C.W. (1999) Physiological adaptations involved in alkane assimilation at low temperatures by Rhodococcus sp. strain Q15. Appl. Environ. Microbiol. 65, 2961-2968.

[24] Warhurst, A.W. and Fewson, C.A. (1994) Biotransformations catalyzed by the genus Rhodococcus. Crit. Rev. Biotechnol. 14, 29-73.

[25] Smits, T.H.M., Röthlisberger, M., Witholt, B. and van Beilen, J.B. (1999) Molecular screening for alkane hydroxylase genes in Gramnegative and Gram-positive strains. Environ. Microbiol. 1, 307-318.

[26] Vomberg, A. and Klinner, U. (2000) Distribution of alkB genes within $n$-alkane-degrading bacteria. J. Appl. Microbiol. 2000, 339-348.

[27] Smits, T.H.M., Balada, S.B., Witholt, B. and vanBeilen, J.B. (2002) Functional analysis of alkane hydroxylases from Gram-negative and Gram-positive bacteria. J. Bacteriol. 184, 1733-1742.

[28] Van Beilen, J.B., Smits, T.H.M., Whyte, L.G., Schorcht, S., Röthlisberger, M., Plaggemeier, T., Engesser, K.-H. and Witholt, B. (2001) Alkane hydroxylases in Gram-positive strains. Appl. Environ. Microbiol. (submitted).

[29] Centre d'expertise en analyse environnementale du Québec (1997) Méthode d'analyse-Sols-Dosage des hydrocarbures pétroliers $\left(\mathrm{C}_{10}\right.$ à $\mathrm{C}_{50}$ ), 1st edition. Ministère de l'environnement et de la faune du Québec, MA.410-HYD. 1.0, $10 \mathrm{pp}$.

[30] Fortin, N., Fulthorpe, R.R., Grant Allen, D. and Greer, C.W. (1998) Molecular analysis of bacterial isolates and total community DNA from kraft pulp mill effluent treatment systems. Can. J. Microbiol. 44, 537-546.

[31] Flemming, C.A., Leung, K.T., Lee, H., Trevors, J.T. and Greer, C.W. (1994) Survival of lux-lac marked biosurfactant-producing 
Pseudomonas aeruginosa UG2L in soil monitored by nonselective plating and PCR. Appl. Environ. Microbiol. 60, 1606-1613.

[32] Berthelet, M., Whyte, L.G. and Greer, C.W. (1996) Rapid, direct extraction of DNA from soils for PCR analysis using polyvinylpolypyrrolidone spin columns. FEMS Microbiol. Lett. 138, 17-22.

[33] Sambrook, J. (1989) Molecular Cloning: A Laboratory Manual. Cold Spring Harbor Laboratory, Cold Spring Harbor, NY.

[34] Coates, J.D., Ellis, D.J., Blunt-Harris, E.L., Gaw, C.V., Roden, E.E. and Lovley, D.R. (1998) Recovery of humic-reducing bacteria from a diversity of environments. Appl. Environ. Microbiol. 64, 1504-1509.

[35] Greer, C., Masson, L., Comeau, Y., Brousseau, R. and Samson, R. (1993) Application of molecular biology techniques for isolating and monitoring pollutant-degrading bacteria. Water Pollut. Res. J. Can. 28, 275-287.

[36] Juck, D., Charles, T., Whyte, L.G. and Greer, C.W. (2000) Polyphasic microbial community analysis of petroleum hydrocarbon contaminated soils originating from 2 northern Canadian communities. FEMS Microbiol. Ecol. 33, 241-249.

[37] Eriksson, M., Ka, J.-O. and Mohn, W.W. (2001) Effects of low tem- perature and freeze-thaw cycles on hydrocarbon biodegradation in Artic tundra soil. Appl. Environ. Microbiol. 67, 5107-5112.

[38] Wardell, L.J. (1995) Potential for bioremediation of fuel-contaminated soil in Antarctica. J. Soil Contam. 4, 111-121.

[39] Ward, D.M., Weller, R. and Bateson, M.M. (1990) 16S rRNA sequences reveal numerous uncultured microorganisms in a natural community. Nature 345, 63-65.

[40] Lloyd-Jones, G. and Hunter, D.W.F. (2001) Comparison of rapid DNA extraction methods applied to contrasting New Zealand soils. Soil Biol. Biochem. 33, 2053-2059.

[41] Tani, A., Ishige, T., Sakai, Y. and Kato, N. (2001) Gene structures and reuglation of the alkane hydroxylase complex in Acinetobacter sp. strain M1. J. Bacteriol. 183, 1819-1823.

[42] Leahy, J.G. and Colwell, R.R. (1990) Microbial degradation of hydrocarbons in the environment. Microbiol. Rev. 54, 305-315.

[43] Kok, M., Oldenhuis, R., van der Linden, M.P.G., Raatjes, P., Kingma, J., van Lelyveld, P.H. and Witholt, B. (1989) The Pseudomonas oleovorans alkane hydroxylase gene: sequence and expression. J. Biol. Chem. 264, 5435-5441. 